\title{
Violation prooxidative-antioxidant stability at maize shoots at different level of accumulation of cadmium and nickel
}

\author{
Tatiana Artyushenko - Vitalii Gryshko \\ Plant Physiology and Soil Biology Department, Kryvyi Rig Botanic Garden of the National Academy of Sciences of Ukraine, \\ Ukraine, Kryvyi Rig, Marshak st., 50, e-mail:vit.grishko@rambler.ru
}

Keywords: maize, cadmium, nickel, stress, lipid peroxidation, ascorbate peroxidase

\section{SUMMARY}

Joint influence of cadmium and nickel was investigated on the feature of their accumulation by the vegetative organs of 10-days' old maize shoots. It was established that most intensively noted metals are taken in by the roots of shoots in the first 7 hours stressing influencing, while in leaves they appear only after a 7-hour long exposition. It was stated that the absorption process of the noted metals by a root system is carried by two-phase character. The indexes of inner-tissue contamination are calculated. Activating by the cadmium and nickel ions of lipid peroxidation as marker of the stressing influencing, and also was shown the proper increase of intensity of functioning of ascorbate peroxidase as the antioxidant enzyme protection of cell.

\section{INTRODUCTION}

In the complex processes of environmental inhibition - one of the strongest factors of biosphere components destruction - an important role is played by heavy metals. Emissions of their bonds from anthropogenic sources, ability to form high local concentrations, chemical stability and ambiguous biological functions, in particular capability of the negative operating on the agrocenosis components, determine the increase of researchers attention to the heavy metals (Kervesan el al., 2001; Laspina et al., 2005; Rucinska-Gwozdz, 2005).

In development of general adaptation syndrome of organisms to the surplus heavy metals in an environment one of the first heterospecific conversions there is activating of lipid peroxidation, which results in alteration of plants metabolism both at the cell level and all of organism (Gryshko-Syshchykov, 1999; Platonova-Kostyshin, 2000; Schutzendubel et al., 2001). Bias of prooxidative-antioxidative equilibrium in the conductor of activating of lipid peroxidation is the call to start of stress conversion. It is known together with it, that at unfavorable conditions and, in particular, under action of nickel ions (Pandolfini et al., 1992), manganese (Pands et al., 1987), copper (Luna et al., 1994), cadmium (Platonova-Kostyshin, 2000), fluorine (Gryshko-Syshchykov, 1999), there is activating of lipid peroxidation processes, what the increase of innate of malonyl dyaldehyde testifies to (Dovgalyuk et al., 2002.).

However a necessary condition for normal vital cells functions support is balanced between peroxidation, from one side, and by antioxidative activity, from the other. Therefore for uncontrolled oxidation cascades breaking in every organoid antioxidants and antioxidant enzymes systems function, key role among which in chloroplasts and cytozol of higher plants plays ascorbate peroxidase (E.C. 1.11.1.11), which belongs to hemeperoxidases and catalyzes neutralization of hydrogen peroxide. It is set for today, that different stress factors ambiguously influence on enzyme activity. It was investigated by A.Schutzendubel that cadmium increased enzyme activity in the Scots pine (Pinus sylvestris) roots at first, and after a 24-h sentinel exposition declined (Schutzendubel et al., 2001). In the conditions of anoxia at a pea and wheat ascorbate peroxidase activity in the leaves in rose considerably (Mittova-Igamberdiev, 1998). Next to it, at a maize at low temperature stress effects ascorbate peroxidase activity in leaves declines sharply, that limits of its cryophylactic on the ontogenetic development early stages (Hull et al., 1997).

However much questions of violation prooxidative-antioxidant plant systems functioning density are unknown at the stress factors action conditions, in particular at the joint effect of heavy metals. Together with it, also the characteristics of cadmium and nickel accumulation are not investigated by the rootage of plants at their compatible function and subsequent distribution of metals in "root-leave" system. Thus, the analysis of literary data allows to establish, that lipid peroxidation processes development and antioxidant enzymes functioning at the conditions of cadmium and nickel joint action on plant organisms until now remains not found out and needs the detailed investigation, that was the goal of our work.

\section{MATERIALS AND METHODS}

The researches objects were the hybrid Blitz $160 \mathrm{MV}$ maize shoots (Zea mays L.), that was grown in distilled water. On the 10 day of experiment to the growing environment brought in heavy metals in next concentrations 3 $\mathrm{mg} \mathrm{Cd}^{2+} / 1+4 \mathrm{mg} \mathrm{Ni}^{2+} / 1 ; 3 \mathrm{~m} \mathrm{Cd}^{2+} / 1+40 \mathrm{mg} \mathrm{Ni}^{2+} / 1 ; 30 \mathrm{mg} \mathrm{Cd}^{2+} / 1+4 \mathrm{mg} \mathrm{Ni}^{2+} / 1 ; 30 \mathrm{mg} \mathrm{Cd}^{2+} / 1+40 \mathrm{mg} \mathrm{Ni}^{2+} / 1$. The samples of plants took away through 1, 7, 12 and 24 hours after heavy metals application. Content of cadmium and nickel in vegetable material was determined by the atomic-adsorption spectrophotometer of C-115 in obedience to the generally accepted methods (Feldman, 1974). 
Intensity of lipid peroxidation development is estimated after maintenance of TBA-active products (Kamishnikov, 2000). Ascorbate peroxidase activity was determined according to Nakano Y. and Asada K. (Nakano-Asada, 1981), proteine concentration- was measured by the method of Greenberg Ch.S. (GreenbergGaddock, 1982).

\section{RESULTS AND DISCUSSION}

Researches of heavy metals accumulation degree by the maize shoots roots at growing for the cadmium and nickel actions have an intensive absorption already at first hour of the stressing influencing. Maintenance of nickel ions in roots at bringing in the growing medium toxicants mixture in the low concentration exceeded the controls values more than on $70 \%$, and cadmium almost three times (Table. 1). Next to it, influencing of toxicants combination, when even one element was brought in high concentration, the accumulation was more intensive in the roots. For example, at nickel predominance the accumulation level of both metals grew twice comparatively with a previous variant, while the shoots exposition is on an medium which contains $4 \mathrm{mg} \mathrm{Ni}^{2+} / 1$ and $30 \mathrm{mg} \mathrm{Cd}^{2+} / 1$ resulted in the increase of concentration last in 9.6, and nickel - in 3.3 times comparatively with the control.

Got experimental information allow to establish, that in the conditions of contamination by a cadmium and nickel with the increase of the stressing influencing duration to 7 hours there was strengthening of toxicants accumulation by the shoots roots. At the compatible action of metals in the low concentrations cadmium maintenance exceeded the controls values in 5-7 times, while at the high concentrations - in 10-15 times. Together with it, substantial intensification of nickel absorption by roots tissues in the experiments variants with the low nickel concentration on a 7 hours of the stressing influencing comparatively with the first hour of growing was not observed. However during the high concentration absorption was increased on 40-60\% (Table 1).

The subsequent lengthening of toxicants duration action to 12 hours did not cause the increase of metals absorption levels by the maize shoots rootage. On the fixed fact absence specifies statistically reliable difference of the proper values of maintenance both pollutants after 7 and 12 hours expositions on cadmium and nickel solutions. Similar above-mentioned tendency was experienced in relation to deceleration of toxicants absorption processes by the maize shoots rootage, with the increase of intoxication duration to 24 hours.

That the most intensive metals accumulation by the shoots roots is marked on a 7 hour of the stressing influencing, whereupon the process of absorption went out on a plateau and a linear phase which was characterized by permanent low speed of absorption came.

At research of cadmium and nickel accumulation processes in the vegetative organs maize shoots the considerably higher accumulation of metals is marked in rootage tissues comparatively with leaves. The result of functioning of the plants protective systems is explanation of the above-mentioned conformity to the law, in particular Kaspary belts of root, which to a certain extent hinder to the toxicants receipt of in above-ground part of plants.

According to the results presented in tables we can establish, that on the initial stage (1 hour after metals bringing) of cadmium and nickel stressing action in the experiments variant where its were brought in the low concentrations their maintenance did not differ from the control. After the 7-hours shoots exposition on solutions which contain mixture with the low cadmium concentration it was not marked increase of it accumulation. However in other variants there was intensification of toxicants accumulation in an assimilatory apparatus. For the actions of a $4 \mathrm{mg} \mathrm{Ni}^{2+} / 1$ and $30 \mathrm{mg} \mathrm{Cd}^{2+} / 1$ maintenance last was in 1.5 times, and at the complex influencing of high metals concentration - almost twice as high, than in the control shoots leaves. Together with it, it is necessary to mark that for a nickel only on the toxicants actions in the low concentration there was no increase of piling up in leaves tissues. In all other variants growth of accumulation levels was marked on 21 and $43 \%$ for the actions of mixture with predominance of cadmium and nickel accordingly, while at the high concentrations of metals on $-96 \%$.

Shoots exposition on solutions with low heavy metals maintenance during 12 hours resulted in intensification of nickel accumulation in leaves on $30 \%$, while the concentration of cadmium statistically for certain did not differ from the control. At the same time in the shoots leaves which tested the metals mixture action with high maintenance even one of them, a tendency is traced to deceleration of nickel accumulation rates as compared to information for 7 hours. However receipt of cadmium in leaves tissues in the variants marked higher and its accumulation grew in 1.7-2 times.

The analysis of heavy metals accumulation processes by the shoots leaves during 24-hours their action allowed to set that intensity of nickel accumulation remains at that level, that and after 12- hours stress, and during the high cadmium concentration there is the halt of growth of piling up rates last.

Thus, the facts resulted higher allow to assert that cadmium and nickel absorption by the maize shoots rootage is had by two-phase character. During the first 7 hours there was rapid toxicants absorption, which in corresponde with the literary information answers the satiation by the metals of xylem vessels (Mel'nichuk, 1990, Yang et al., 1997). A linear phase which is characterized by permanent speed of cadmium and nickel accumulation comes farther. 
Cadmium and nickel content in the vegetative organs of maize shoots $\mathrm{mg} / \mathrm{g}$ of dry weight

\begin{tabular}{|c|c|c|c|c|}
\hline \multirow{3}{*}{ Variant } & \multicolumn{2}{|c|}{ roots } & \multicolumn{2}{|c|}{ leaves } \\
\hline & $\mathrm{Cd}$ & $\mathrm{Ni}$ & $\mathrm{Cd}$ & $\mathrm{Ni}$ \\
\hline & $\mathrm{M} \pm \mathrm{m}$ & $\mathrm{M} \pm \mathrm{m}$ & $\mathrm{M} \pm \mathrm{m}$ & $\mathrm{M} \pm \mathrm{m}$ \\
\hline \multicolumn{5}{|c|}{1 hour } \\
\hline Control & $0.58 \pm 0.044$ & $8.73 \pm 1.140$ & $0.15 \pm 0.021$ & $1.04 \pm 0.037$ \\
\hline $3 \mathrm{mg} \mathrm{Cd}^{2+} / 1+4 \mathrm{mg} \mathrm{Ni}^{2+} / 1$ & $1.72 \pm 0.074 *$ & $15.10 \pm 1.473^{*}$ & $0.16 \pm 0.005$ & $1.16 \pm 0.129$ \\
\hline $3 \mathrm{mg} \mathrm{Cd}^{2+} / 1+40 \mathrm{mg} \mathrm{Ni}^{2+} / 1$ & $3.36 \pm 0.045^{*}$ & $37.94 \pm 3.499 *$ & $0.18 \pm 0.011$ & $1.16 \pm 0.069$ \\
\hline $30 \mathrm{mg} \mathrm{Cd}^{2+} / 1+4 \mathrm{mg} \mathrm{Ni}^{2+} / 1$ & $5.56 \pm 0.477 *$ & $28.73 \pm 3.226^{*}$ & $0.18 \pm 0.024$ & $1.06 \pm 0.039$ \\
\hline $30 \mathrm{mg} \mathrm{Cd}^{2+} / 1+4 \mathrm{mg} \mathrm{Ni}^{2+} / 1$ & $7.82 \pm 0.548 *$ & $43.92 \pm 3.71^{*}$ & $0.17 \pm 0.039$ & $1.13 \pm 0.036$ \\
\hline \multicolumn{5}{|c|}{7 hours } \\
\hline Control & $0.57 \pm 0.018$ & $8.43 \pm 0.904$ & $0.14 \pm 0.010$ & $1.00 \pm 0.053$ \\
\hline $3 \mathrm{mg} \mathrm{Cd}^{2+} / 1+4 \mathrm{mg} \mathrm{Ni}^{2+} / 1$ & $3.10 \pm 0.077 *$ & $16.04 \pm 1.985^{*}$ & $0.16 \pm 0.012$ & $1.06 \pm 0.118$ \\
\hline $3 \mathrm{mg} \mathrm{Cd}^{2+} / 1+40 \mathrm{mg} \mathrm{Ni}^{2+} / 1$ & $3.91 \pm 0.008 *$ & $52.43 \pm 2.100 *$ & $0.16 \pm 0.013$ & $1.64 \pm 0.088^{*}$ \\
\hline $30 \mathrm{mg} \mathrm{Cd}^{2+} / \mathrm{l}+4 \mathrm{mg} \mathrm{Ni}^{2+} / 1$ & $5.76 \pm 0.569 *$ & $30.17 \pm 2.853 *$ & $0.21 \pm 0.019^{*}$ & $1.21 \pm 0.019^{*}$ \\
\hline $30 \mathrm{mg} \mathrm{Cd}^{2+} / 1+4 \mathrm{mg} \mathrm{Ni}^{2+} / 1$ & $8.70 \pm 1.441^{*}$ & $58.56 \pm 3.98 *$ & $0.27 \pm 0.009 *$ & $1.96 \pm 0.182 *$ \\
\hline \multicolumn{5}{|c|}{12 hours } \\
\hline Control & $0.59 \pm 0.045$ & $8.52 \pm 0.707$ & $0.16 \pm 0.022$ & $1.01 \pm 0.053$ \\
\hline $3 \mathrm{mg} \mathrm{Cd}^{2+} / 1+4 \mathrm{mg} \mathrm{Ni}^{2+} / 1$ & $3.11 \pm 0.128 *$ & $17.30 \pm 2.244^{*}$ & $0.17 \pm 0.011$ & $1.34 \pm 0.122 *$ \\
\hline $3 \mathrm{mg} \mathrm{Cd}^{2+} / 1+40 \mathrm{mg} \mathrm{Ni}^{2+} / 1$ & $4.03 \pm 0.432 *$ & $57.19 \pm 4.186^{*}$ & $0.23 \pm 0.018^{*}$ & $2.01 \pm 0.226^{*}$ \\
\hline $30 \mathrm{mg} \mathrm{Cd}^{2+} / 1+4 \mathrm{mg} \mathrm{Ni}^{2+} / 1$ & $6.16 \pm 0.311 *$ & $31.20 \pm 3.336^{*}$ & $0.43 \pm 0.0045^{*}$ & $1.92 \pm 0.183 *$ \\
\hline $30 \mathrm{mg} \mathrm{Cd}^{2+} / \mathrm{l}+4 \mathrm{mg} \mathrm{Ni}^{2+} / 1$ & $8.64 \pm 0.697 *$ & $63.98 \pm 14.268 *$ & $0.45 \pm 0.035^{*}$ & $2.13 \pm 0.024 *$ \\
\hline \multicolumn{5}{|c|}{24 hours } \\
\hline Control & $0.87 \pm 0.003$ & $8.47 \pm 0.899$ & $0.17 \pm 0.039$ & $1.04 \pm 0.050$ \\
\hline $3 \mathrm{mg} \mathrm{Cd}^{2+} / 1+4 \mathrm{mg} \mathrm{Ni}^{2+} / 1$ & $3.52 \pm 0.050 *$ & $33.23 \pm 1.832 *$ & $0.27 \pm 0.025 *$ & $1.68 \pm 0.079 *$ \\
\hline $3 \mathrm{mg} \mathrm{Cd}^{2+} / 1+40 \mathrm{mg} \mathrm{Ni}^{2+} / 1$ & $4.08 \pm 0.705 *$ & $59.52 \pm 3.045^{*}$ & $0.28 \pm 0.032 *$ & $2.20 \pm 0.094 *$ \\
\hline $30 \mathrm{mg} \mathrm{Cd}^{2+} / 1+4 \mathrm{mg} \mathrm{Ni}^{2+} / 1$ & $6.58 \pm 0.499 *$ & $43.23 \pm 3.582 *$ & $0.47 \pm 0.007 *$ & $2.00 \pm 0.089 *$ \\
\hline $30 \mathrm{mg} \mathrm{Cd}^{2+} / \mathrm{l}+4 \mathrm{mg} \mathrm{Ni}^{2+} / 1$ & $9.34 \pm 1.127 *$ & $68.85 \pm 6.075^{*}$ & $0.50 \pm 0.037 *$ & $2.35 \pm 0.275 *$ \\
\hline
\end{tabular}

$*_{-}$statistically a reliable difference is in relation to control at $\mathrm{p}<0.05$

The results achieved allow to assert that the compatible metals action substantially displaces a prooxidativeantioxidant balance both in leaves tissues, and maize shoots roots, causing activating of lipid peroxidation. About growth of lipid peroxidation processes intensity in the maize shoots vegetative organs testifies the increase of maintenance of TBA-active products in roots on $19 \%$ in relation to controls shoots, however in an assimilatory apparatus their amount did not change (Figure 1). More intensive motion of peroxidation processes was observed in the variants of experiments, when even one of metals was brought in the high concentration. Growth of TBA-active products maintenance is the certificate of the above-mentioned tendency in roots on the average on $50 \%$, and in leaves on $20 \%$ it is comparative by the control. On the first hour of experiment the most substantial growth of levels of TBA-active products formation was marked for shoots at the compatible toxicant action in the high concentration - in 3 and 1.5 times in a rootage and leaves accordingly.

At the increase of cadmium and nickel joint action duration to 7 and 12 hours a tendency is marked in relation to growth of TBA-active products concentration, both in roots and in the shoots leaves. Most intensification of peroxidation processes on a 12 hours of stressing getting is set in a variant with the use of high concentration of both metals, by the certificate what maintenance of TBA-active products twice higher comparatively with the first hour is in the shoots vegetative organs.

Intoxication of maize plants by cadmium and nickel salts during 24 hours resulted in subsequent intensification of lipids peroxidation processes. The level of TBA-active products in leaves grew in 2,5-4 times in relation to the control, that in 1.3-2.2 times exceeds the similar values the proper variants after the 12-hours stressing action. For the shoots roots is characteristic similar tendency. However in a rootage the amount of the peroxidation products in 1.3-1.9 times exceeds the noted index in of assimilatory tissues.

It is known that lipids peroxidation activating, caused by the stressings factors of different nature results in the start of numeral mechanisms of cell defense, among which a considerable role belongs to antioxidative systems enzymes, in particular ascorbate peroxidase. Researches of ascorbate peroxidase activity are conducted in the maize shoots roots allowed to set that cadmium and nickel compatible influencing already on the initial stage of stressing action results in substantial growth of noted enzyme activity. The sentinel shoots exposition is on solutions which contain metals low concentration mixture stimulated the increase of ascorbate peroxidase activity on $30 \%$ comparatively with the control (Figure 2a). At the complex action, when even one metal was brought in the high concentration intensity of ascorbate peroxidase functioning rose in 1.8-2 times, while high maintenance of both metals in an solution stipulated growth of enzyme activity values almost three times. 
Figure 1. Content of TBA-active products in the vegetative organs of maize shoots
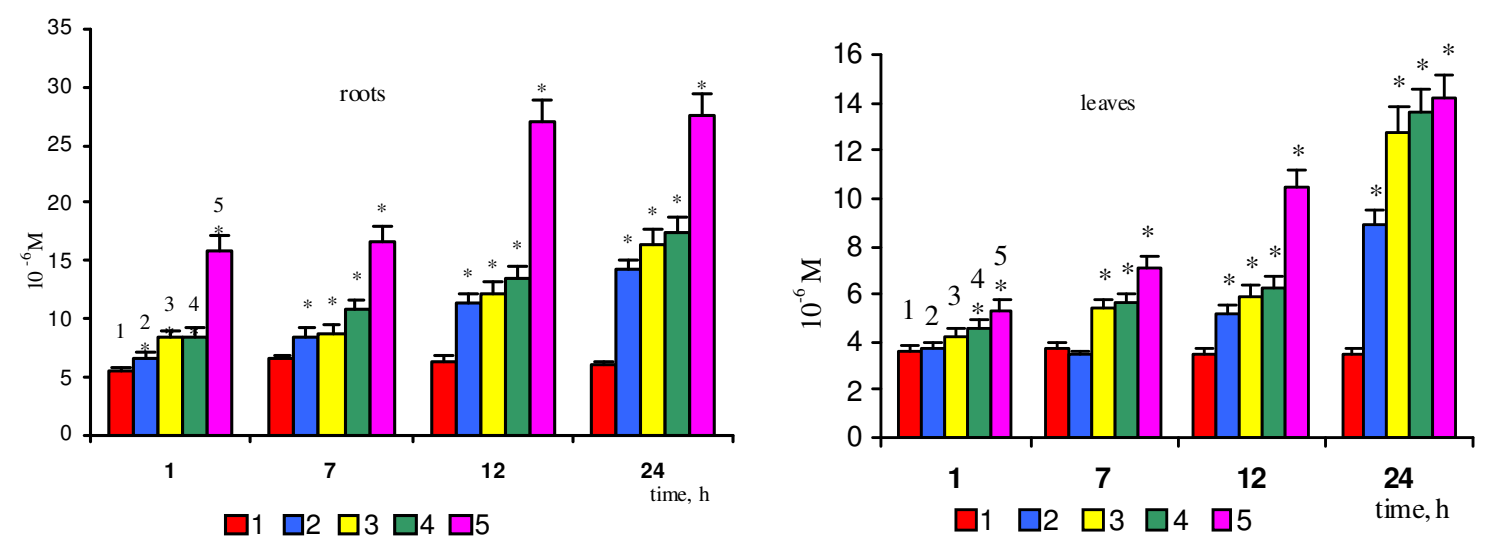

1 - control; $2-3 \mathrm{mg} \mathrm{Cd}^{2+} / 1+4 \mathrm{mg} \mathrm{Ni}^{2+} / 1 ; 3-3 \mathrm{mg} \mathrm{Cd}^{2+} / 1+40 \mathrm{mg} \mathrm{Ni}^{2+} / 1 ; 4-30 \mathrm{mg} \mathrm{Cd}^{2+} / 1+4 \mathrm{mg} \mathrm{Ni}^{2+} / 1 ; 5-30 \mathrm{mg} \mathrm{Cd}^{2+} / 1+40 \mathrm{mg}^{2}$ $\mathrm{Ni}^{2+} / \mathrm{l} ; *$ - statistically reliable difference is in relation to control at $\mathrm{p}<0.05$

With the increase of the stressing influencing duration to 7 hours there was the subsequent increase of ascorbate peroxidase activity in the shoots roots. During the low concentration of cadmium and nickel connections comparatively with the first hour its growth is marked on 5\%. In the experiments variants with the use of nickel in the high concentration and cadmium in low the noted peroxidase functioned already on $10 \%$ more active, while at predominance in the medium of cadmium - on $37 \%$ comparatively with a 1 hour of intoxication. Subject to the condition compatible influencing of high concentrations of metals is marked considerable intensification of ascorbate peroxidase functioning, about what the increase of enzyme activity values testifies three times comparatively with a 1 hour of the stressing influencing, that in 7.6 times exceeds controls levels.

The increase of shoots exposition duration on heavy metals solutions to 24 hours resulted in deceleration of rates of ascorbate peroxidase growth activity. At a cadmium and nickel low to maintenance in the growing medium intensity of enzyme functioning exceeded the proper after 12-hours stress on $16 \%$, while for the actions of mixture with nickel predominance the increase of activity is marked only $6 \%$. In all other experience variants of activity value on a 24-hour stress statistically for certain did not differ from 12-hours.

The data analysis of models experiments rotined that in the maize shoots leaves (Figure 2) in a hour after the complex cadmium and nickel compounds bringing ascorbate peroxidase activity did not exceed the controls values. The above-mentioned is explained by dependence of antioxidant enzymes functioning on the rates of metals accumulation by tissues and from lipids peroxidation intensity. On a 7 hour of experiment for the actions of low toxicants concentration ascorbate peroxidase activity in the shoots leaves also statistically for certain did not differ from the control.

Figure 2. Ascorbate peroxidase activity in the vegetative organs of maize shoots (mkM ascorbic acid/mg proteine*30 seconds)

roots

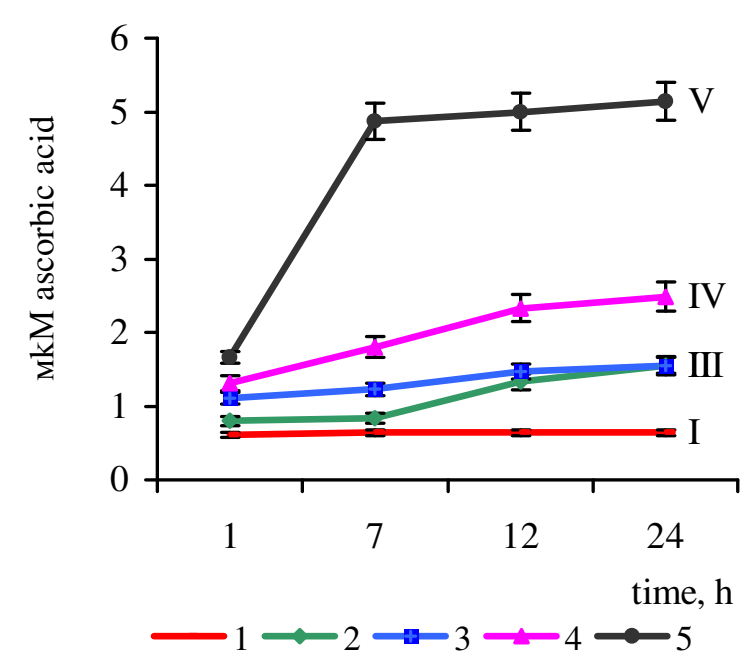

leaves

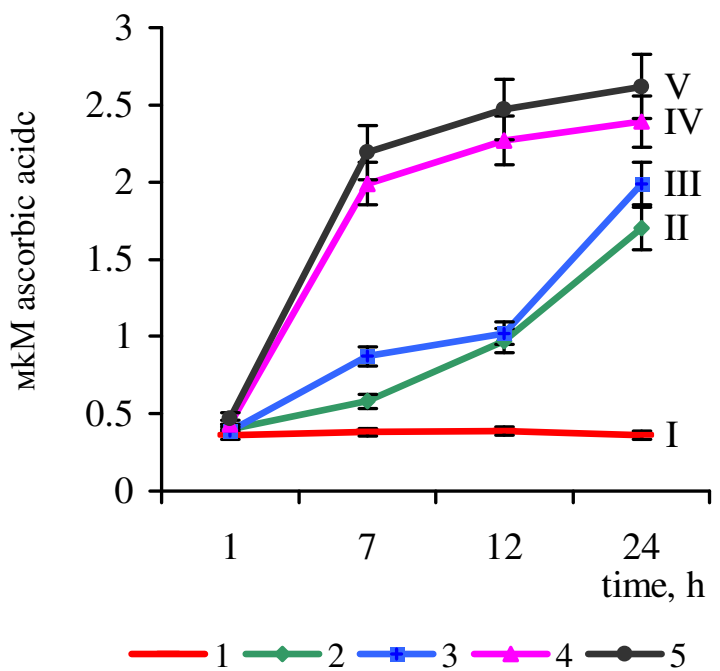



$\mathrm{Ni}^{2+} / \mathrm{l}$.

1 - control; $2-3 \mathrm{mg} \mathrm{Cd}^{2+} / 1+4 \mathrm{mg} \mathrm{Ni}^{2+} / 1 ; 3-3 \mathrm{mg} \mathrm{Cd}^{2+} / 1+40 \mathrm{mg} \mathrm{Ni}^{2+} / 1 ; 4-30 \mathrm{mg} \mathrm{Cd}^{2+} / 1+4 \mathrm{mg} \mathrm{Ni}^{2+} / 1 ; 5-30 \mathrm{mg} \mathrm{Cd}^{2+} / 1+40 \mathrm{mg}$

Together with it compatible influencing of metals, where even one was in the high concentration, stimulated the growth of enzyme functioning intensity in 2.3 and 5.2 times at predominance of nickel and cadmium accordingly. At the same time subject to the condition toxicants complex bringing in the growing medium in the high concentrations ascorbate peroxidase activity in leaves was almost in 6 times higher, than in controls shoots.

The results of researches confermed that the shoots exposition on heavy metals solutions during 12 hours resulted in subsequent growth of ascorbate peroxidase activity in leaves. Thus only on the actions of low concentrations of cadmium and nickel noted enzyme functioning intensity was multiplied on $67 \%$, while in all other experiments the increase only made on the average $14 \%$ comparatively with a 7-hours pollutants action.

At the increase of the cadmium and nickel ions compatible influencing time to 24 hours the similar is marked above-described tendency in the maize shoots leaves to the proper experiments variants after a 12-hours exposition. It is necessary only to mark that at bringing of low concentrations of both metals salts and in the variant of nickel high concentration on background low cadmium there was more intensive increase of values of ascorbate peroxidase activity, than in other variants.

\section{CONCLUSIONS}

Summing up the results of research work it is possible to state that cadmium and nickel at the compatible action is most intensively taken in by the maize shoots rootage during the first 7 hours stressing influencing, speed of their accumulation is considerably moderate where upon. That, in this case it is possible to talk about two-phase character of the noted metals absorption. Together with it, the toxicants accumulation in assimilatory tissues took place only after a 7-hours exposition and grew with lengthening of the stressing influencing duration and with increase of concentration of metals. The cadmium and nickel toxic action on the early stages of maize ontogenesis appears in violation of prooxidative-antioxidative balance, which is confirmed by intensification of lipids peroxidation processes as primary markers of the stressing influencing, and also the proper increase of ascorbate peroxidase activity - one of key enzymes of antioxidant defense.

\section{REFERENCES}

Dovgalyuk A.I. - Kalinyak T.B. - Blyum Ya.B. (2002): Specific effects of toxic metals ions on the microtubes of meristimatic roots cells of Allium cepa L. // Dopovidi Nacional National academy of sciences of Ukraine, 1. 162-168.

Feldman C. (1974): Perchloric acid procedure for wetashing organics for the determination of mercury (and other metals). Anal. Chem., 46. 1606-1609.

Greenberg Ch.S. - Gaddock Rh.R. (1982): Rapid single step membrane proteine assay. Clin. Chem., 28: 7. 1726-1728.

Gryshko V.M. - Syshchykov D.V. (1999): Lipid peroxidation and some antioxidant enzymatic system functioning in maize and oat under the acute HF injury. The Ukrainian Biochemical Journal, 71: 3. 51-57.

Hull M.R. - Long S.P. - Jahnke L.S. (1997): Instantaneous and development effects of low temperature on the catalytic properties of antioxidant enzymes in two Zea species. Aust. J. Plant Physiol., 24. 337-343.

Kamishnikov V.C. (2000): Reference book on clinical-biochemical laboratory diagnostics. - Minsk.: Byelorussia.

Kervesan S. - Petrovic N. - Popuvic M. - Kandrac J. (2001): Nitrogen and protein metabolism in young pea plants as affected by different concentrations of nickel, cadmium, lead and molybdenum. Plant Nutr., 24: 10. 1633-1644.

Laspina N.V. - Groppa M.D. - Tomaro M.L. - Benavides M.P. (2005): Nitric oxide protects sunflower leaves against Cd-induced oxidative stress. Plant Sci., 169. 323-330.

Luna C.M. - Gonzalez C.A. - Trippi V.S. (1994): Oxidative damage caused by an excess of copper in oat leaves. Plant Cell Physiol., 35. 11-15.

Mel'nichuk Yu.P. (1990): Influence of cadmium ions on a cellular division and growth of plants. - Kiev: Naukova dumka

Mittova V.O. - Igamberdiev A.U. (1998): Operation of ascorbate-glutathione cycle in higher plants under the conditions of anoxia. Bulg. J. Plant Physiol.: Sp. Is. 288.

Nakano Y. - Asada K. (1981): Hydrogen peroxide is scavenger by ascorbate-specific peroxidase in spinach chloroplasts. Plant and Cell Physiol., 22: 5. 867-880.

Pandolfini T. - Gabrielly R. - Vergnano O. (1992): $\mathrm{Ni}^{2+}$ effects on lipid peroxidation and free radical defence enzymes in Triticum aestivum. Physiol. Plant., 85: 3. 70

Pands S. - Mishra A.K. - Biswal U.C. (1987): Manganese induced peroxidation of thylakoid lipids and changes in chlorophyll-a fluorescence during aging of cell free chloroplasts in light. Phytochemistry: 26: 12. 3217-3219.

Platonova A.A. - Kostyshin S.S. (2000): Content of the malonyl dyaldehyde and activity of the antixidation enzymes in pea sprouts under the effect of cadmium ions. Physiology and biochemistry of cultivated plants, 32: 2. 146-150.

Rucinska R. - Gwozdz E.A. (2005): Influence of lead on membrane permeability and lipoxigenase activity in lupine roots. Biol. Plant., 49. 617-619.

Schutzendubel A. - Schwanz P. - Teichmann T. - Gross K. - Langenfeld-Heyser R. - Godbold D.L. - Polle A. (2001): Cadmiuminduced changes in antioxodative systems, hydrogen peroxide content, and differentiation in Scots pine roots. Plant Physiol., 127: 887898. 
Yang X.E. - Baligar V.C. - Foster J.S. - Martens D.C. (1997): Accumulation and transport of nickel in relation to organic acids in ryegrass and maize grown with different nickel levels. Plant Soil, 196. 271-276. 